inventories are neither unaffordable nor unmanageable and they produce a more than reasonable return for the effort expended. It might, therefore, be prudent for library managers to resist the urge to reject such a project out-of-hand simply because the holdings are large. In closing, a "catch-22" admonition may be in order: if a sample inventory at a library is confusing and expensive (slow), it probably indicates that a complete inventory is badly needed.

\title{
Purposes and Uses of Residence Hall Libraries
}

\section{Gail Oltmanns and John H. Schuh}

This paper describes a study of student use and perceptions of their residence hall libraries at Indiana University. A telephone survey of students in residence centers and a user survey conducted in the libraries were the two methods used to collect the data. The responses indicate that students do, in fact, use their residence hall libraries. Most frequently, they use the magazine and newspaper collections. Records and audiocassettes, class-related materials, and study space are also frequently cited as popular uses. Because there are other libraries on campus that serve the academic needs of students, $i$ seems reasonable to develop residence hall library collections to fulfill the supplemental, leisure-reading needs of student residents.

Libraries have been developed in residence halls for a variety of reasons. Residence hall libraries enrich the educational experience of resident students, provide easy access for students who have reference questions, and serve the general library needs of students by making books, magazines, newspapers, records, and tapes available to students in the place where they live. Furthermore, residence center libraries may ease the demand for study space and materials in the main library.

The first residence hall libraries were started at Harvard in 1928 where a library was developed within each of seven houses. This system became the model for future residence hall library systems.
Soon after Harvard established its house libraries, B. Lamar Johnson established six dormitory libraries at Stephens College in Missouri. Yale created nine college libraries and a number of other colleges and universities developed residence hall library systems, although their scope and level of sophistication varied considerably. Some of these programs disappeared, however, due to lack of interest or financial support. Others grew stronger. Specific reasons that contributed to colleges and universities sustaining the viability of residence hall libraries included adequate funding for the purchase of current materials, adequate staff, and the security of materials in the libraries. The University of Michigan and Indiana UniversityBloomington (IUB) currently operate the largest residence hall library systems with eleven in each system.

Although residence hall libraries have existed for more than fifty-five years, little has been published about them. Several articles appeared in the 1930 s that discussed the Harvard system, ${ }^{1}$ the Stephens College dormitory libraries, ${ }^{2}$ and a dormitory library established at the University of Chicago. ${ }^{3}$ Harvie Branscomb (1940) devoted a chapter of Teaching with Books to the discussion of residence halls libraries. He argued that books should be available to students in their residence centers because, "on a college campus, which exists for teaching purposes, books should be in

Gail Oltmanns is assistant head, undergraduate library services, and John $\mathrm{H}$. Schuh is associate dean of students and director of residence life, Indiana University, Bloomington, Indiana 47405. 
the atmosphere. ${ }^{\prime 4}$ Between 1940 and the late $1960 \mathrm{~s}$ a few articles were published that primarily discussed individual library systems. A detailed description of the University of Michigan system appeared in 1968. Onva Boshears and Gary Strong described a use survey which had been conducted in one of the dormitories. They distributed questionnaires to 1170 residents of a dormitory. More than one thousand questionnaires were completed and returned. The data showed that "only eighteen percent indicated that they never used the library, while eleven percent indicated active use on either a daily or weekly basis, and seventy-one percent reported occasional use of the library. ${ }^{\prime 5}$ This report represents one of the few times that data were collected that described how frequently and for what purposes the residential unit library was used.

In 1969 Edward Stanford conducted a survey of institutions with residence hall libraries. He discussed why some libraries had failed and outlined the characteristics of successful programs. ${ }^{6}$ Following Stanford's article almost nothing appeared in the literature until 1978 when Susan Ariew published her study of "open access" residence hall libraries. ${ }^{7}$ Her conclusions regarding the failure of "open access" policies resulted from a literature review and responses to a questionnaire mailed to institutions that had residence hall libraries.

At Indiana University, libraries are located in each of the eleven single student residence centers. The first of these libraries was opened in 1941 and the collection was financed by profits from vending machines located in the residence halls. As profits increased libraries were added to other residence halls. By 1969 all halls had libraries.

The libraries are open fifty-eight hours per week and are managed by graduate assistants who are students in the School of Library and Information Science. In addition to the graduate assistants, four to seven part-time student employees are assigned to each library. The libraries contain a variety of materials and equipment: hardcover books including reference materials, paperback books, newspapers, magazines, records, audiocassettes, videocassettes, art prints, and equipment such as typewriters, calculators, and player/recorders. The average number of books per library is 7,000 and each library holds approximately 1,200 records and tapes. Stated succinctly, the purpose of the Halls of Residence Libraries (HRL) system is to assist in meeting the cultural, recreational, and academic needs of students who live in the residence centers.

The study conducted at Indiana University was designed to measure the perceptions of students about selected aspects of the residence hall libraries. Several questions guided the study:

1. For what general purposes do students use the residence hall libraries?

2. How frequently do students use the residence hall libraries?

3. What specific library services are utilized by patrons of the residence hall libraries?

4. Why do infrequent users of the residence hall libraries not use the libraries more frequently?

\section{METHOD}

The study was conducted in two parts. The first part sought the perceptions of a randomly selected group of students who participated in a telephone survey. The second part of the study involved collecting the perceptions of students who participated in a survey of users of the residence hall libraries during a two-week period of time.

\section{Sampling}

The telephone survey was conducted with a sample of 1,050 students (approximately 10 percent of the residence hall population). The telephone numbers of students living in the residence halls were drawn randomly from a room-by-room roster of students living in the residence halls in March 1983. One hundred telephone numbers were drawn for residence halls housing 1,000 or more students $(\mathrm{N}=10)$ and 50 were drawn for the one residence hall that housed 550 students. A total of 735 students participated in the telephone interviews for a response rate of 70 percent. 
The users' survey was conducted in late March and early April 1983. Any student who used a residence hall library during this time could complete the survey questionnaire. Ultimately, 535 users completed the survey.

\section{Instrumentation}

All the items for the telephone survey were highly structured and elicited a yes or no answer or a very short response. A brief pilot study was conducted to make sure that the items were easily understood by the respondents.

Items for the users' survey were prepared in consultation with professional librarians. The questionnaire was reviewed by several students for clarity and understandability before it was distributed.

\section{Data Collection}

Data were collected in the telephone survey by making calls to the numbers that had been drawn. In most cases four students shared the same telephone, so any one of the four could have responded to the call. Student workers administered the questionnaire to the respondents.

The questionnaires for the participants in the users' survey were provided to potential respondents through each residence hall library. Users were asked by the center librarians or other library workers to complete the instrument in the library and return it to the library employee.

\section{Data Analysis}

All data were transferred from the questionnaire to computer coding sheets from which computer cards were made. The data were analyzed by computer using SPSS programs. Data analysis included developing measures of central tendency and frequency distributions on an itemby-item basis.

\section{RESULTS}

Most participants in each survey indicated that they used the library as a place to study. Other purposes were for recreational reading, to listen to records and tapes, for class-related materials and to check out art prints. These data are listed in table 1.

The second question examined the frequency with which residence hall libraries were used. Predictably, the respondents used the libraries more frequently than did the participants in the telephone survey. Most often, the respondents to the users' survey indicated that they used the libraries "several times a week," while "'a few times a month" was the most frequent response of the participants in the telephone survey. Responses to this item ranged from "never" to "daily" usage of the residence hall libraries and are included in table 2.

The services provided by residence hall libraries was the next area of inquiry for this study. Most often, students used the libraries to read magazines, to study, and to read newspapers. Least often, the respondents to the users' survey used a tool rental service and checked out art prints from the library. These data are summarized in table 3 .

The telephone survey examined why infrequent users (less than once a month or never) of the libraries did not use the residence hall libraries more often. Most often, they reported that they preferred to use another library on campus or that the residence hall library did not have the ma-

TABLE 1

USES OF HALLS OF RESIDENCE LIBRARIES

\begin{tabular}{|c|c|c|c|c|}
\hline \multirow{2}{*}{ Purpose } & \multicolumn{2}{|c|}{$\begin{array}{l}\text { Respondents to } \\
\text { Telephone Survey }\end{array}$} & \multicolumn{2}{|c|}{$\begin{array}{l}\text { Respondents to } \\
\text { Users' Survey }\end{array}$} \\
\hline & & & & $\%$ \\
\hline To study & 271 & 69.7 & 458 & 92.5 \\
\hline For recreational reading & 224 & 57.6 & 397 & 80.7 \\
\hline For records and tapes & 188 & 48.3 & 390 & 76.5 \\
\hline For class-related materials & 187 & 48.1 & 375 & 74.6 \\
\hline For art prints & 42 & 10.8 & 233 & 44.7 \\
\hline For other reasons & 115 & 29.6 & 144 & 27.1 \\
\hline
\end{tabular}


TABLE 2

FREQUENCY OF USE OF HALLS OF RESIDENCE LIBRARIES

\begin{tabular}{lrrrrr}
\hline \hline & \multicolumn{2}{c}{$\begin{array}{c}\text { Respondents to } \\
\text { Frequency }\end{array}$} & \multicolumn{2}{c}{ Respondents to } \\
No. & None Survey* & \multicolumn{2}{c}{ Users' Survey $^{*}$} \\
\hline Daily & 18 & 2.4 & 64 & \multicolumn{1}{c}{ No. } \\
Several times a week & 102 & 13.9 & 223 & 41.7 \\
A few times a month & 259 & 35.2 & 189 & 35.3 \\
Less than once a month & 183 & 24.9 & 42 & 7.9 \\
Never & 156 & 21.2 & 0 & 0.0 \\
No response & 17 & 2.3 & 17 & 3.2 \\
\hline
\end{tabular}

*Does not equal $100 \%$ due to rounding.

TABLE 3

USES OF HALLS OF RESIDENCE LIBRARIES BY RESPONDENTS TO USERS' SURVEY

\begin{tabular}{|c|c|c|c|c|}
\hline \multirow[b]{2}{*}{ Service } & \multicolumn{4}{|c|}{ Response* } \\
\hline & Yes & $\%$ & No & $\%$ \\
\hline Read magazines & 382 & 75.2 & 126 & 24.8 \\
\hline Study & 307 & 60.9 & 197 & 39.1 \\
\hline Read newspapers & 281 & 54.0 & 239 & 46.0 \\
\hline Check out records & 208 & 40.5 & 305 & 59.5 \\
\hline Check out books for leisure reading & 191 & 37.2 & 322 & 62.8 \\
\hline Check out books related to class work & 187 & 35.4 & 341 & 64.6 \\
\hline Check out tapes & 127 & 24.2 & 398 & 75.8 \\
\hline Listen to tapes & 67 & 12.8 & 456 & 87.2 \\
\hline Check out reserve materials & 55 & 10.5 & 470 & 89.5 \\
\hline Check out equipment like typewriters and calculators & 54 & 10.3 & 469 & 89.7 \\
\hline Check out art prints & 53 & 10.1 & 471 & 89.9 \\
\hline RHA tool service rental & 27 & 5.1 & 498 & 94.9 \\
\hline
\end{tabular}

*Nonrespondents to specific items are not included in this table.

terials they needed. The library being too crowded or too noisy and not knowing about or not being able to find the library were reasons that were not listed frequently. These data are summarized in table 4.

\section{Telephone Survey}

\section{CONCLUSIONS}

Of the random sample of 735 students in the telephone survey, over half the sample reported using the libraries frequently (a few times a month or more often). Just 22 percent of those surveyed indicated that they never use HRL.

Over half the frequent users use HRL for recreational reading. Of the frequent users, 92.5 percent use HRL as a place to study. If providing a place to study seems inconsistent with the objectives of HRL, it should be pointed out that while users do study in the libraries, they might at the same time use reference or reserve materi- als or listen to reserve tapes. They might also use newspapers or magazines during study breaks or as sources of information for class assignments.

Infrequent users do not use HRL more frequently because they prefer to use another library on campus. Just over half of the infrequent users reported that HRL did not have the materials they needed. Many of these students might be users of the main library or one of the fourteen more specialized branch libraries on campus. About 25 percent of the infrequent users find the facilities uncomfortable.

Students in the random sample are generally aware of services provided by HRL whether they use the libraries frequently or infrequently. It cannot be construed, then, that some students are infrequent or nonusers due to a lack of knowledge of the libraries. Most of them simply prefer to use another library.

The low percentage of use of art prints is 
TABLE 4

WHY INFREQUENT USERS DO NOT USE THE HALLS OF RESIDENCE LIBRARIES

\begin{tabular}{|c|c|c|c|c|}
\hline \multirow[b]{2}{*}{ Reason } & \multicolumn{4}{|c|}{ Response* } \\
\hline & Yes & $\%$ & No & $\%$ \\
\hline Don't know about it & 19 & 5.5 & 326 & 94.5 \\
\hline Can't find it & 9 & 2.6 & 335 & 97.4 \\
\hline Library is too crowded & 29 & 8.5 & 313 & 91.5 \\
\hline Library is too noisy & 40 & 11.7 & 303 & 88.3 \\
\hline Facilities are uncomfortable & 85 & 24.9 & 257 & 75.1 \\
\hline Library does not have the materials I need & 171 & 50.6 & 167 & 49.4 \\
\hline Library is not open when I want to use it & 75 & 21.9 & 267 & 78.1 \\
\hline Prefer to use another library on campus & 281 & 83.1 & 57 & 16.9 \\
\hline Just don't like it & 98 & 28.6 & 245 & 71.4 \\
\hline Other reasons & 128 & 37.4 & 214 & 62.6 \\
\hline
\end{tabular}

"Nonrespondents to specific items are not included in this table. explained by the small number of prints available (approximately one hundred prints per library) and the circulation period (one semester).

\section{User Survey}

The 535 students who filled out questionnaires in their center libraries were asked to report their perceptions of HRL purposes and services. These students indicated that more than half of them use their libraries a few times a week or daily. Most often, users of HRL reported that they perceived the purpose of the libraries is to provide places to study. A substantial majority also reported that the libraries should satisfy their needs for recreational reading, records and tapes, and classrelated materials.

Their reasons for using the libraries were not inconsistent with their perceptions of the purposes. Respondents reported that they used the library most often to read magazines and newspapers, and to study. They used the library very infrequently to check out reserve materials, equipment, art prints, or tool kits. In addition, a majority of users found HRL employees helpful and operating hours convenient.

\section{SUMMARY}

The data collected in this study indicated that students who live in the residence centers have a wide range of library needs that extended from very general, recreational, leisure-reading, and listening needs to basic reference and academic, curriculum-supporting needs. These needs

can be determined by looking at the ways in which frequent users actually use the Halls of Residence Libraries. They can also be determined by examining the purposes the respondents think the libraries should serve.

Responses to questions asked in the two phases of the study (telephone survey and users' survey) strongly suggested that a variety of needs are being met by HRL. The data also indicated that some of these needs are being met better than others. For example, while some students used HRL for class-related materials, many more students used the libraries for current periodicals and leisure reading. Records and tapes also were very popular and heavily used.

In planning residence hall libraries, the data suggest that residence hall libraries can best be developed to meet the leisure reading needs of residential students. As a result, collections probably should be developed along the lines of including magazines and newspapers, followed in importance by class-related materials and records and tapes. Art prints, reserve materials, and equipment are not used frequently by students and should have a lower priority than magazines and newspapers, records and tapes, and classrelated materials. It seems reasonable to conclude that residence hall libraries should meet the general public library needs of students who live in residence, and that academic needs can be met by other libraries within the campus library system. 


\section{REFERENCES}

1. Kenneth Morgan, "The Harvard House Libraries," Library Journal 56:538 (June 13, 1931).

2. B. Lamar Johnson, "Dormitory Libraries at Stephens College," Library Quarterly 5:218 (Apr. 1935),

3. Leon Carnovsky, "The Dormitory Library: An Experiment in Stimulating Reading, " Library Quarterly 3:41 (Jan. 1933).

4. Harvie Branscomb, Teaching with Books (Chicago: Association of American Colleges, American Library Assn., 1940).

5. Onva K. Boshears and Gary E. Strong, "The Residence Hall Library," Wilson Library Bulletin 42:829 (Apr. 1968).

6. Edward B. Stanford, "Residence Hall Libraries and Their Educational Potential," College \& Research Libraries 30:198 (May 1969).

7. Susan Andriette Ariew, "The Failure of the Open Access Residence Hall Library," College \& Research Libraries 39:372 (September 1978).

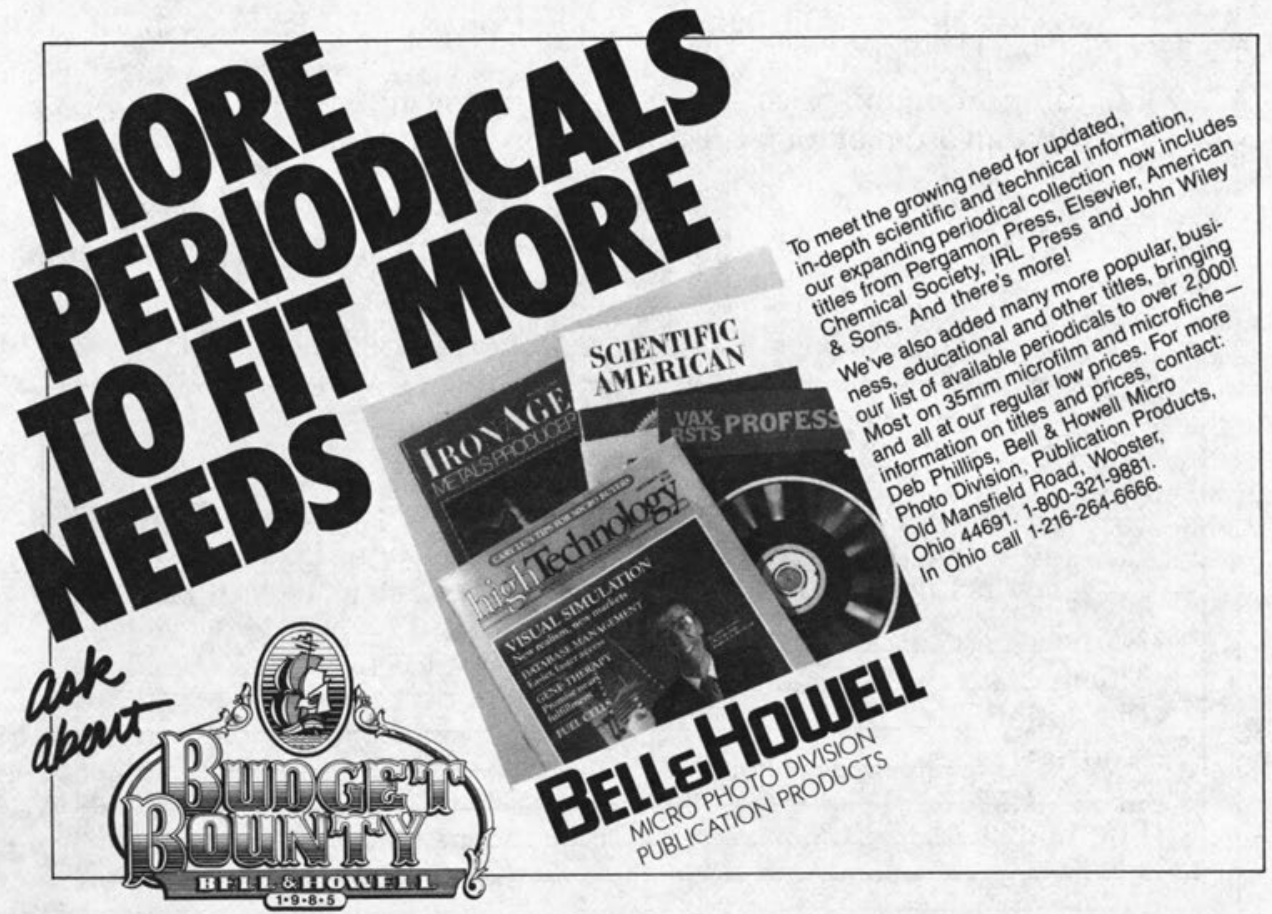




\section{Chapter and Verse.}

300 Years of American Fiction and Poetry

As the United States emerged and grew, its heritage and development was reflected in its literature. In these two microfilm collections, Research Publications presents an invaluable resource for scholars of American history and culture.

\section{American Fiction, 1774 to 1910}

The country dealt with its potential, changed, and faced difficulties. This collection follows the development of an ever-changing culture through the works of both well-known and lesser-known writers. Novels, short stories, tales, sketches, and allegories are some of the works included in this 10,800 title, 1,645 reel collection.

- Now available for acquisition on standing order.

- $36 \frac{1}{2}$ subscription units.

- Standing order unit price $-\$ 1,970$ (15\% off the individual unit price)

\section{American Poetry, 1609 to 1870}

Approximately 9,600 titles thoroughly sample the poetry of the period on 425 reels. They also reflect the attitudes and sentiments of the times through works by obscure as well as major poets and poetic works of prose authors.

- Now available for acquisition on standing order.

- 11 subscription units.

- Standing order unit price $-\$ 2,275$ ( $15 \%$ off the individual unit price)

To place an order or for more information, call or write:

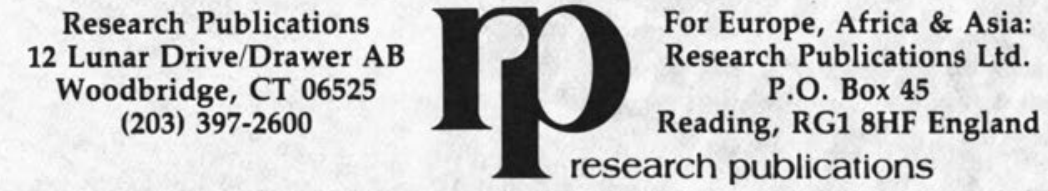

TWO fOr the ShOW.
I wish to place
an order. Please
contact me.
Name Alease forward more information on
Title American Fiction, 1774 to 1910 .
Institution
Address
City
Phone

